\title{
How consistent is teachers' planning, implementation, and assessment in character education?
}

\author{
Budiarta Luh Gd Rahayu*, Artini Luh Putu, Seken I Ketut and Santosa Made Hery \\ English Education Department, Universitas Pendidikan Ganesha, Bali, Indonesia
}

\begin{abstract}
This descriptive case study aims at investigating how teachers planned, practiced, assessed students' character development in the classroom. The study involved 29 students of Grade 5, a classroom, and an English teacher. The instruments include classroom observation, checklist, interview guide, field note, and video recording. The obtained data were analyzed by using analysis method by Miles and Huberman (1994). The result of the research shows that there were ten characters values detected in the lesson plans, however, only 55\% consistently appeared in the teaching and learning process. Teachers were found to use performance rubrics and diary to keep record on students' character development. The interview revealed that there was reluctance regarding role of teacher in term of assessing students' characters. This fact implies that there should be intensive training and workshop for the teachers to improve the quality of the character education practices in elementary schools in Bali.
\end{abstract}

Keywords: Curriculum 2013, Character education, Teacher's planning, Practicing, Assessing

\section{Introduction}

One of the latest issues in Indonesia's education is the launching of Curriculum 2013 which promotes character building as the highest priority. It can be seen from the core competencies (KI) which are explicitly stated in the document. Character is important manifestation of educational implementation process in every level [1]. It means that character building should be reflected in each learning subject, and not only in certain lessons related to attitude, such as religion, civics, and norms. Character education is very important, not only to help the country's young generations to be 'good', but also help them reach academic achievement [2].

The character education is a deliberate effort aims to cultivate and develop character that are worthy for individual and sociey as a whole [3]. It requires careful and calculated planning for success [4]. Other researcher found character education programs had a positive effect on both character development and academic success [5]. It will increase the nation quality in the future. Creating good a character based education in school is very important to do [6]. Schools, as an education institution, have a very important role in cultivating children character through education [7]. So that, planning the character based education must be done as good as possible by the teachers. Good planning will guide to

* Corresponding author : budiartarahayu@gmail.com 
good implementation of the character education [8].At the moment, this curriculum has not been officially regulated yet in all schools in Indonesia. However, some schools have already applied it based on the government decision, or the schools are appointed as piloting schools. The goverment choose one elementary school in Denpasar in Grade 5 as a subject or model in implementing Curriculum 2013. All teachers in the school had joined workshop in implementing the curriculum. Some of them had joined for three times. In addition, the teachers had also given technical books of the curriculum to be learnt. If they find any problems, they can ask the school's supervisor. Here, the supervisor becomes a bridge between the teachers and the government.

However, based on the interview done with the teachers, they have serious problem on the assessment. It might be caused by the teachers' perception of using previous conventional assessment, but in the current curriculum, they are expected to use more authentic assessment. In addition, the assessment system for the character education undergoes frequent changes. Before, the assessment was conducted per theme, and then changed into per sub-theme. Until this research was finished, there is still no fixed assessment for the character education, because it keeps changing. It makes the teachers remain in confusion regarding how to assess the students' characters.

Based on those explanations, the research comes to complete the previous researches by adding some points on research, namely the planning of the character based education, the implementation of the character based education, the way of assessing it, and the encountered problems. According to Curriculum 2013, the subjects are divided into obligatory and local content subjects; therefore this research focused on both of them. The obligatory lesson is in form of thematic, meanwhile the local content one is not. Here, the selected local content subjects was English. It is done in accordance with the researcher's specialty.

Based on the previous explanation, this paper focuses on 1) how the fifth grade teacher plans the character-based education, 2) how the fifth grade teacher practices the characterbased education, 3) how the fifth grade teacher assesses the character-based education, and 4) the problems faced by the teachers in implementing the character-based education.

\section{Methods}

This research is a descriptive case study whose data were collected as it is. This research was conducted at primary school in Denpasar considering the school as one of piloting schools that implements Curriculum 2013. The subjects of the research were the fifth grade thematic teacher, the fifth grade English teacher, and 29 students of the school under the study; meanwhile the object of the study was the teaching learning process of the character education which involved the way of teacher planning, practicing, and assessing the character education. In order to collect the expected data, three methods of data collection were used, namely observation/recording, interview, and document study. The researcher served as the main instrument who collected the data, observed the phenomena, conducted analysis, and concluded the result of the analysis. To gather the data, the researcher used some devices, such as interview guide, tape-recorder, and video-recorder. The obtained data were analyzed by using analysis method proposed by Miles and Huberman [9]. 


\section{Results and Discussion}

This research was done in one of elementary schools piloting Curriculum 2013 in the municipality of Denpasar. Here, there were two lessons observed, e.g. thematic and English. The finding of the research is presented in Table 1.

Table 1. The summary of character inserted in thematic and English lesson

\begin{tabular}{|l|l|c|c|c|c|c|c|}
\hline \multirow{2}{*}{ No } & \multicolumn{2}{|c|}{ Characters } & \multicolumn{6}{c|}{ Thematic and English Lessons } \\
\cline { 3 - 8 } & & LP & $\begin{array}{c}\text { Prac } \\
\text {-tice }\end{array}$ & $\begin{array}{c}\text { Assess- } \\
\text { ment }\end{array}$ & LP & $\begin{array}{c}\text { Prac- } \\
\text { tice }\end{array}$ & $\begin{array}{c}\text { Assess- } \\
\text { ment }\end{array}$ \\
\hline 1 & Religiosity & $\sqrt{ }$ & $\sqrt{ }$ & $\sqrt{ }$ & $\sqrt{ }$ & $\sqrt{ }$ & - \\
\hline 2 & Tolerance & - & $\sqrt{ }$ & - & - & $\sqrt{ }$ & - \\
\hline 3 & Hardwork & $\sqrt{ }$ & $\sqrt{ }$ & - & $\sqrt{ }$ & $\sqrt{ }$ & - \\
\hline 4 & Communicativeness & $\sqrt{ }$ & $\sqrt{ }$ & - & $\sqrt{ }$ & $\sqrt{ }$ & - \\
\hline 5 & Independence & $\sqrt{ }$ & $\sqrt{ }$ & - & $\sqrt{ }$ & $\sqrt{ }$ & - \\
\hline 6 & Democracy & $\sqrt{ }$ & $\sqrt{ }$ & - & - & - & - \\
\hline 7 & Curiosity & - & - & - & - & - & - \\
\hline 8 & Discipline & - & $\sqrt{ }$ & - & - & - & - \\
\hline 9 & Responsibility & $\sqrt{ }$ & $\sqrt{ }$ & $\sqrt{ }$ & - & $\sqrt{ }$ & - \\
\hline 10 & Nationality & $\sqrt{ }$ & $\sqrt{ }$ & - & - & - & - \\
\hline 11 & Patriotism & - & - & - & - & - & - \\
\hline 12 & Appreciation for Achievement & - & $\sqrt{ }$ & - & - & - & - \\
\hline 13 & Love for Peace & - & - & - & - & - & - \\
\hline 14 & Love for Reading & $\sqrt{ }$ & $\sqrt{ }$ & - & - & - & - \\
\hline 15 & Social Care & - & - & $\sqrt{ }$ & - & - & - \\
\hline 16 & Creativity & $\sqrt{ }$ & $\sqrt{ }$ & - & - & $\sqrt{ }$ & - \\
\hline 17 & Nature care & $\sqrt{ }$ & $\sqrt{ }$ & - & - & - & - \\
\hline 18 & Honesty & - & $\sqrt{ }$ & $\sqrt{ }$ & - & - & - \\
\hline
\end{tabular}

Based on Table 1, it is known that among 18 characters established by the government, there were only 10 characters planned by the classroom teachers. In the practice, 14 characters were practiced. It means that the other 4 characters occured simultanously. For the assessment practice, there were only 4 characters which were completed with assessment system. For English teacher, there were 4 characters planned from 18 established characters by the government. However, there were only 7 characters practiced. It means that 3 characters were practiced simultanously. English teacher did not make assessment for the characters.

The finding reveals that the teacher had professionally planned character based education. The experience and knowledge acquired from the workshop are very useful in making the planning. The teacher realized that they must have good decision and creative thinking in order to plan their lesson well [10]. By doing good planning of the character based education, the school can be a place for the students to develop or to cultivate the characters. It allows the school to function as a facilitator of academic and non academic skills to develop [11].

In planning, the teachers included explicit and implicit focuses of character during teaching and learning process. There are three strategies can be used in teaching the character based education, namely a) explicit focus of specified character values/ethics, b) involvement of students in interactive pedagogical activities, and c) provision of characters 
modelling [12]. The explicit focus is exemplified by giving advice directly to the students regarding what they are allowed and not allowed to do. Meanwhile, the implicit information is done by involving the students in teaching and learning process, i.e. by implementing group discussion technique. Here, the students are taught to be communicative and respectful the others' opinion.

From Table 1, it is known that there are ten characters consistently taught by the teacher, namely religiousity, hardwork, communicative, independence, democracy, responsibility, nationality, love for reading, creativity and nature care. Those characters are consistently appeared in teaching learning process. After knowing how many characters appeared in teaching learning process. Next, it is showed the percentage of each practiced character as Table 2 .

Table 2. Frequency of the Character Practiced

\begin{tabular}{|l|l|c|c|}
\hline No & \multicolumn{1}{|c|}{ Character } & $\begin{array}{c}\text { Frequency in } \\
\text { Thematic }\end{array}$ & $\begin{array}{c}\text { Frequency in English } \\
(\mathbf{\%})\end{array}$ \\
\hline 1 & Religiosity & $22 \%$ & $22 \%$ \\
\hline 2 & Hard work & $55 \%$ & $38 \%$ \\
\hline 3 & Creativity & $11 \%$ & $11 \%$ \\
\hline 4 & Independence & $22 \%$ & $22 \%$ \\
\hline 5 & Democratic & $55 \%$ & $38 \%$ \\
\hline 6 & Curiosity & $44 \%$ & $22 \%$ \\
\hline 7 & Nationalism & $44 \%$ & $0 \%$ \\
\hline 8 & Communicativeness & $66 \%$ & $44 \%$ \\
\hline 9 & Love for reading & $44 \%$ & $0 \%$ \\
\hline 10 & Nature care & $22 \%$ & $0 \%$ \\
\hline 11 & Responsibility & $44 \%$ & $0 \%$ \\
\hline
\end{tabular}

Among all, $22 \%$ of the character practiced by both teachers was religious; meanwhile for the classroom teachers, $55 \%$ practiced character was hardworking, and the English teacher had the practice by $38 \%$. Relious character was practiced at the beginning and the end of learning; meawhile, the hard working character was practiced through assignment and exercise during the learning process. Next, the communicative character in which the classroom teacher practiced by $66 \%$ and the English teacher did by $44 \%$. This character was practiced through the implementation of coooperative learning. In addition, English teacher also applied independent character by the same percentage. By this model, the students were expected to interact and communicate with each other. At the end, they had to be able to do something independently. Next, the classroom teacher practiced creative character by $11 \%$, independence character was inserted by $22 \%$ during the planning and the implementation, and the characters of curious, nationalism, love for reading and responsible was integrated during teaching learning process by $44 \%$. The creative character was cultivated by giving the students freedom in accomplishing their assignment based on the instruction; the independent character was practiced by giving individual project or assignment; the curious character was practiced by giving authentic task; nationalism character was practiced by hanging heroes picture and celebrating national day; love for reading character was done by directing the students to visit library; responsible character was practiced by assigning them with group work with responsibility organizing the class in a prepared schedule. The English teacher also did the same thing as classroom teacher. Lastly, democratic character was found by $38 \%$. Democratic was also practiced by carrying out discussion on certain activities, and nature care was done by keeping the environment clean and conducting socialization about the importance of nature. 
The application of character education should concern on three interrelated parts, namely moral knowledge, moral feeling, and moral action [13]. Those three interrelated parts of good character can be taught in the classroom during learning activities by involving the students in any projects that can increase students' awareness, teaching the students how to respect and be responsible, analyzing the moral values integrated in the lesson, deciding the moral values aimed to deliver in the learning process, searching for decent learning material, designing effective learning strategies, inviting keynote speaker to discuss particular character values, and doing multicultural education to build students' understanding about different culture [14].

In the implementation of the character education at the piloting school, all parts of the education character have been practiced. The characters have been integrated in the lessons. Besides that, the teachers also applied scientific approach in the class in which the character can be inserted. Here, only "inviting keynote speaker to discuss particular character values" was not done by the school. The knowledge regarding the character values was obtained by the teachers through workshops or seminars.

In term of assessment, the teachers provided lack of assessment for the characters, even the English teacher did not assess the students' characters. Until now, the classroom teacher only used diary and rubric. It is not considered as good, since assessment plays asignificant role in the development of students character [15]. In addition, Character Educational Partnership or CEP stated, in the character education, assessment serves as the source of information about the students' characters [16]. Good assessment leads to appropriate treatment that should be given to the students. If the assessment does not provide holistic information, the teacher may not treat the students' character well [17]. As the consequence, using and developing good assessment instruments can be a way taken to reach the character education's success. There must be two assessment types for effectiveness of the character education, they are pre-assessment of goals and postassessment of results [18].

\section{Conclusion}

Based on the analysis, the character education has been planned by the teachers in the classroom. Based on the result of analysis conducted on four lesson plans, there were ten characters appeared constantly in the learning process. After that, both thematic and English teachers have already practiced all characters planned in the lesson plans.

Until now, the teachers only use rubric and daily journal. The rubric is used in certain subject lesson with clear descriptors for each character. Meanwhile, the daily journal is used to record the students' bad attitudes on daily activities that will be used to score the students in every one semester.

The teacher still have problem in implementing character education, there were four problems encountered by the thematic teacher in implementing character education, namely a) unclear procedure of assessment, b) the different rules applied by the school and parents at home, c) the teachers' lack of IT knowledge, and d) the lack of media, such as books and magazines containing character building. Meanwhile, for the English teacher, there were only two problems encountered regarding the unclear procedure of assessment, and the different rules applied by parents and the school

This research implied that there should be intensive training and workshop for the certainty regarding the character assessment procedure and supervision of the goverment stakeholders given for improving the character education. 


\section{References}

1. A. Darmansyah,. The development of character education curriculum for elementary student in west sumatera., 2, 189-198 (2014)

2. L Artini. Integrating universal and local values in character education in indonesian schools. (2016)

3. G.M. Almerico. Building Character through Literacy with Children's Literature (2014).

4. C. Tyra. Bringing books to life: Teaching character education through children's literature. Rising Tide, 5, 1-10 (2012)

5. A. Katilmis., H. Eksi \& C. Ozturk, C. (2011). Efficiency of social studies integrated character education program. Educational Sciences: Theory \& Practice 11, 36-50 (2011)

6. A. Djailani. Strategy character building of students at excellent schools in the city of banda aceh. 1, 49-59 (2013).

7. M. Elias. Character Education: Better student better people. (2010).

8. S. Jacques S. Benninga., Marvin W. Berkowitz., Phyllis, Kuehn., Karen, Smith. The Relationship of Character Education Implementation and Academic Achievement In Elementary School. JR. CE. 1(1). 19-3. (2003)

9. M. A. Miles. In qualitative data analysis: an expanded sourcebook, 50-72(1994).

10. Twemlow, S. W., Fonagy, P., Sacco, F., Gies, M. L., Evans, R., \& Ewba nk, R. Creating a Peaceful School learning environment: A controlled study of an elementary school intervention to reduce violence. A. J. Psych. 158. 808-810. (2001)

11. Vaishnavi. R. Kanzal, Subikshalakshmi. G, Lopamudra Goswami. Moral Education: Current Values in Students and Teachers' Effectiveness in Inculcating Moral Values in Students. I. J. I. Psych. 4(1), No. 81. (2016)

12. M. W. Berkowitz, \& Bier, M. C. (2007). What Works in Character Education. Journal of Research in Character Education.

13. T. Lickona. What is good character? (2001).

14. F. Clark, P. With Liberty and Justice for All Character Education for America's Future .J. CE. 10(1). 31-36. (2014) 10

15. Supriyadi, E. Pengembangan Pendidikan Karakter di Sekolah. (2012)

16. Ministry of Education and Culture. (2013). Peraturan Menteri Pendidikan dan Kebudayaan Republik Indonesia Nomor 65 Tahun 2013 tentang Standar Proses Pendidikan Dasar dan Menengah.

17. Haryanto. Pendidikan karakter menurut ki hadjar dewantara. 53, 1689-1699 (2013)

18. K. M. Brooks B. What makes character education programs work? 51, 19-21 (1993) 